\title{
Dokumenty archiwalne dotyczące orzecznictwa karno-administracyjnego w sprawach związanych z działalnością polskiego Kościoła rzymskokatolickiego w latach 1960-1961
}

\section{Wstęp}

Prezentowany poniżej dokument zawiera sprawozdanie $\mathrm{z}$ „przebiegu orzecznictwa karno-administracyjnego w sprawach o wykroczenia kleru i aktywu przykościelnego". Sprawozdanie obejmuje drugi, trzeci i czwarty kwartał $1960 \mathrm{r}$. oraz trzy pierwsze kwartały $1961 \mathrm{r}$. Dokument został sporządzony w październiku 1961 r. przez Departament Społeczno-Administracyjny Ministerstwa Spraw Wewnętrznych. Po 1956 r. jego dyrektorem był Henryk Chmielewski, w okresie stalinowskim organizator sekcji tajnej Sądu Wojewódzkiego w Warszawie ${ }^{1}$. W strukturach tego departamentu funkcjonował Wydział Karno-Administracyjny $^{2}$, który wykonywał przysługujący MSW na mocy ustawy o orzecznictwie karno-administracyjnym ${ }^{3}$ zwierzchni nadzór nad tym orzecznictwem. Nadzór

${ }^{1}$ Sprawozdanie Komisji dla zbadania działalności tzw. „sekcji tajnej” Sądu Wojewódzkiego dla m. st. Warszawy, Archiwum Akt Nowych, zespół akt Prokuratura Generalna PRL, sygn. teczki 950, s. 58.

${ }^{2}$ Wydział Karno-Administracyjny zastąpił w 1958 r. Biuro Nadzoru nad Orzecznictwem Karno-Administracyjnym. Zagadnienia dotyczące zakresu i metody prac nad projektem części szczególnej Prawa o wykroczeniach. Dokument przygotowany 3 czerwca 1960 r. przez Komisje do opracowania projektu Prawa o wykroczeniach, Archiwum Akt Nowych, zespół akt Ministerstwo Sprawiedliwości, sygn. teczki 692, s. 6.

${ }^{3}$ Zgodnie z art. 40 znowelizowanej w 1959 r. ustawy z dnia 15 grudnia 1951 r. o orzecznictwie karno-administracyjnym (Dz.U. Nr 15, poz. 79 z 1959 r.) Minister Spraw Wewnętrznych sprawował zwierzchni nadzór nad działalnością kolegiów. 
ten wyrażał się $\mathrm{w}$ możliwości uchylania prawomocnych orzeczeń kolegiów naruszających prawo oraz w wydawaniu ogólnych wytycznych dotyczących przebiegu orzecznictwa.

Sprawozdanie zostało złożone 8 listopada 1961 r. na ręce Tadeusza Żabińskiego ${ }^{4}$, Dyrektora Urzędu do Spraw Wyznań (UdSW)5. Do kompetencji utworzonego w $1950 \mathrm{r}$. UdSW należały sprawy stosunku państwa do wszelkich wyznań, w tym także wyznania rzymskokatolickiego. Instytucja ta odgrywała ważną rolę $\mathrm{w}$ walce $\mathrm{z}$ religią $\mathrm{w}$ okresie gomułkowskim, gdyż wszelkie działania aparatuadministracji państwowejwobecKościoła byłykonsultowaneiopiniowane przez urząd. Pomimo braku ku temu podstaw prawnych, opinie wydawane przez UdSW miały wiążący charakter dla organów prowadzących formalnie określone postępowania, w tym także kolegiów karno-administracyjnych ${ }^{6}$.

Znaczenie orzecznictwa karno-administracyjnego jako instrumentu walki z religią wynikało z faktu, iż ekipa Gomułki krytycznie oceniła skrajnie represyjny model polityki wyznaniowej cechujący okres stalinowski. W pierwszej połowie lat pięćdziesiątych aparat bezpieczeństwa uciekał się często do stosowania „fizycznych" represji wobec duchowieństwa ${ }^{7}$. Obawa przed reakcjami społecznymi skutkowała uznaniem administracyjnych metod ograniczania wpływów Kościoła za najbardziej skuteczne w popaździernikowych realiach społeczno-politycznych. Ciężar walki z Kościołem spoczywał na terenowych organach aparatu spraw wewnętrznych, który wspierały kolegia karno-administracyjne poprzez stosowanie represji wobec naruszających prawo duchownych i katolików świeckich. Znaczenie polityczne kolegiów skutkowało utworzeniem specjalnych składów orzekających „W sprawach kleru i aktywu przykościelnego”. Specjalne składy orzekające tworzyli najbardziej dyspozycyjni członkowie kolegiów szczebla powiatowego. Byli oni powoływani wspólnie przez terenowe organy spraw wewnętrznych i lokalne instancje partyjne. Poddawano ich przy tym intensywnemu szkoleniu ideologicznemu wzakresie aktualnej sytuacji politycznej oraz stosunków państwo-Kościół ${ }^{8}$. Specyfika działalności specjalnych składów

${ }^{4}$ W 1961 r. Tadeusz Żabiński zastąpił na stanowisku Dyrektora UdSW Jerzego Sztachelskiego.

${ }^{5}$ Urząd do Spraw Wyznań został utworzony na mocy ustawy z dnia 19 kwietnia 1950 r. o zmianie administracji publicznej (Dz. U. Nr 19 z 1950 r.). P. Raina, Kościót - państwo w świetle akt wydziałów do spraw wyznań 1967-1968, Warszawa 1994, s. 5.

${ }^{6}$ Było to konsekwencją przekazania w sposób nieformalny do kompetencji urzędu całokształtu spraw związanych z realizacją polityki wyznaniowej państwa. H. Misztal, A. Mezglewski, Zakres kompetencji, styl działania i cele Urzędu do Spraw Wyznań, [w:] Prawo i polityka wyznaniowa w Polsce Ludowej, A. Mezglewski, P. Stanisz, M. Ordon (red.), Lublin 2005, s. 68-69.

${ }^{7}$ R. Gryz, Władze partyjno-państwowe w Polsce w walce $z$ duchowieństwem (1945-1956), [w:] Represje wobec duchowieństwa kościołów chrześcijańskich $w$ okresie stalinowskim $w$ krajach byłego bloku wschodniego, J. Myszor, A. Dziurok (red.), Katowice 2004.

${ }^{8}$ Projekt uregulowania sprawozdawczości w sprawie przestępczości kleru. Notatka Departamentu Społeczno-Administracyjnego MSW (dalej: DSA MSW) z 1961 r., Archiwum Akt Nowych, zespół akt Urząd do Spraw Wyznań, sygn. teczki 71/42, s. 27. 
orzekających skutkowała wprowadzeniem systemu kwartalnej sprawozdawczości $\mathrm{z}$ przebiegu orzecznictwa karno-administracyjnego w sprawach związanych z działalnością Kościoła, który obowiązywał do 1968 r. ${ }^{9}$

$\mathrm{Z}$ dokumentu wynika, iż u podstaw polityki represyjnej kolegiów legła zasada indywidualizacji winy i kary. W praktyce oznaczało to surowe karanie przedstawicieli duchowieństwa i łagodniejsze traktowanie wspierających Kościół osób świeckich. Zamieszczone w sprawozdaniu dane statystyczne wskazują, że przeważająca część wniosków o ukaranie była skierowana właśnie przeciwko wiernym określanym jako „aktyw przykościelny” ${ }^{10}$. Podstawową karą była grzywna, wymierzana najczęściej w sprawach o przeprowadzanie zbiórek publicznych na cele religijne oraz organizowanie zgromadzeń bez wymaganych prawem zezwoleń. W przypadku skazania za prowadzenie nielegalnej zbiórki publicznej orzekano obligatoryjny przepadek zebranych ofiar. Według sprawozdania znaczne kwoty pieniędzy pochodzące $\mathrm{z}$ nielegalnych zbiórek zdołano przejąć w latach 1959 i 1960. Począwszy od 1961 r. Kościół opracował skuteczne mechanizmy ukrywania uzyskanych z tego źródła dochodów. Kolegia zajmowały się także sprawami związanymi z prowadzeniem zajęć religii w niezarejestrowanych punktach katechetycznych. Konflikt wokół punktów katechetycznych stanowił pokłosie podjętych przez władze w latach 1958-1961 działań mających na celu usunięcie nauki religii ze szkół publicznych ${ }^{11}$.

Prezentowany dokument wskazuje na liczne mankamenty w pracy organów wykrywających wykroczenia (MO), jak też w funkcjonowaniu samych kolegiów. Zdaniem autorów dokumentu, trudności te miały wynikać z silnego oddziaływania Kościoła na społeczności lokalne, w tym także na funkcjonariuszy aparatu państwowego. Stąd też liczne propozycje podjęcia środków zmierzających do poprawy poziomu działalności organów zajmujących się ujawnianiem wykroczeń, jak też samych kolegiów karno-administracyjnych.

W okresie gomułkowskim kolegia ukarały kilkadziesiąt tysięcy osób w sprawach związanych z „nielegalną działalnością kleru oraz aktywu przykościelnego”.

${ }^{9}$ Na mocy zarządzenia dyrektora DSA MSW Z. Orłowskiego z 29 czerwca 1968 r. A. Dudek, Rola Kościoła katolickiego w wydarzeniach marcowych 1968 r. w ocenie władz PRL, [w:] Ze studiów nad dziejami Kościoła i katolicyzmu w PRL, B. Bankowicz, A. Dudek (red.), Kraków 1968, s. 28, przypis 8.

${ }^{10}$ Tendencja ta miała miejsce nie tylko w latach 1960 i 1961, ale także w pozostałych latach okresu gomułkowskiego. W roku 1959 sporządzono 3366 wniosków o ukaranie, z czego 2675 przeciwko osobom świeckim. W 1960 r. (bez II kwartału) liczby te wynosiły odpowiednio 2755 i 2 129, w 1961 r. 2592 i 1 929, a w 1962 r. 1460 i 1 079. Informacja o przebiegu orzecznictwa karno-administracyjnego w sprawach o wykroczenia związane $z$ działalnością kleru rzymsko-kat. $w 1962$ r. oraz w sprawie działalności punktów katechetycznych w IV kwartale 1962 r., Instytut Pamięci Narodowej, Oddział w Warszawie, zespół akt Ministerstwo Spraw Wewnętrznych II, sygn. teczki 7615, s. 56.

${ }^{11}$ A. Dudek, O działaniach antykościelnych władz PRL, "Chrześcijanin w Świecie” 1994, nr 1, s. $196-197$. 
Jednak wymierzane przez nie kary bardziej drażniły niż zastraszały duchowieństwo i wiernych ${ }^{12}$, którzy $\mathrm{w}$ sporze państwo-Kościół opowiedzieli się wyraźnie po stronie prymasa Wyszyńskiego. Podobnie jak pozostałe metody administracyjne, służące zwalczaniu religii rzymskokatolickiej, represja karno-administracyjna nie była w stanie powstrzymać dynamiki rozwoju Kościoła. W latach sześćdziesiątych zdecydowanie poprawił on swoje notowania w społeczeństwie i umocnił się wewnętrznie ${ }^{13}$.

\section{DOKUMENT}

1961 październik 9, Warszawa

Departament Społeczno-Administracyjny Ministerstwa Spraw Wewnętrznych

- informacja z przebiegu orzecznictwa karno-administracyjnego

w sprawach kościelnych.

$\underline{\text { Poufne }}$

Informacja

z przebiegu orzecznictwa karno-administracyjnego w sprawach o wykroczenia związane z działalnością kleru i aktywu przykościelnego

Informacja niniejsza opracowana jest na podstawie materiałów będących w posiadaniu Departamentu.

Ponadto, ostatnio w celu zaktualizowania i wzbogacenia tych materiałów, przeprowadzono kontrole na terenie województw: gdańskiego, lubelskiego, łódzkiego, poznańskiego i m. st. Warszawy. Na terenie tych województw /oprócz województw, które Departament wytypował dla przeprowadzenia kontroli przez aktyw partyjny Wydziału Administracyjnego KC PZPR/ naj-

${ }^{12}$ A. Dudek, Państwo i Kościół w Polsce 1945-1970, Kraków 1995, s. 233.

${ }^{13}$ A. Dudek, R. Gryz, Komuniści i Kościół w Polsce (1945-1989), Kraków 2006, s. 275-276. 
częściej występowały przypadki naruszania przepisów przez kler i tzw. aktyw przykościelny.

\section{Wnioski o ukaranie}

W sprawach o wykroczenia związane z działalnością kleru rzymsko-kat. w okresie trzech kwartałów lat 1960-1961 wpłynęła następująca ilość wniosków o ukaranie:

\begin{tabular}{|l|c|c|c|c|c|c|c|}
\hline \multicolumn{1}{|c|}{ Rok } & $\begin{array}{c}\text { Zbiórki } \\
\text { publ. }\end{array}$ & $\begin{array}{c}\text { Zgroma- } \\
\text { dzenia }\end{array}$ & $\begin{array}{c}\text { Stowa- } \\
\text { rzysze- } \\
\text { nia }\end{array}$ & $\begin{array}{c}\text { Budow- } \\
\text { nictwo } \\
\text { sakralne }\end{array}$ & $\begin{array}{c}\text { Przed- } \\
\text { sięwz. } \\
\text { rozryw. }\end{array}$ & Inne & Razem \\
\hline 1960 & 1.733 & 617 & 21 & 266 & 138 & - & 2.775 \\
$\mathrm{x} /$ & $/ 194 /$ & $/ 310 /$ & $/ 9 /$ & $/ 66 /$ & $/ 47 /$ & & $/ 626 /$ \\
\hline 1961 & 961 & 570 & 53 & 233 & 107 & 39 & 1.963 \\
& $/ 107 /$ & $/ 245 /$ & $/ 12 /$ & $/ 62 /$ & $/ 31 /$ & $/ 2 /$ & $/ 459 /$ \\
\hline
\end{tabular}

$\mathrm{x} /$ dane szacunkowe

Uwaga: w nawiasach podano ilość wniosków sporządzonych na osoby duchowne

W 1961 zaznaczył się spadek ilości wniosków o ukaranie kierowanych do kolegiów karno-administracyjnych za popełnienie wykroczeń związanych z działalnością kleru rzymsko-kat. W ciągu trzech kwartałów 1961 r. wpłynęły 1.963 wnioski o ukaranie a więc o $29 \%$ mniej niż w analogicznym okresie roku ubiegłego /2.775/. W tym samym stosunku, bo z 626 w roku 1960 do 459 w roku bież. zmniejszeniu uległa ilość wniosków sporządzonych na osoby duchowne.

Spadek ilości wniosków o ukaranie za te wykroczenia tłumaczony jest zdecydowanym przeciwdziałaniem - w poprzednich latach - ze strony organów ścigających oraz surowymi represjami karnymi stosowanymi przez kolegia. W dalszym ciągu w 1961 r. liczną grupę wykroczeń stanowią sprawy nielegalnie organizowanych zbiórek publicznych i zgromadzeń. W sprawach zgromadzeń nastąpił nawet w III kw. br. wzrost ilości wniosków o ukaranie $\mathrm{w}$ stosunku do poprzednich kwartałów. Wpłynęło na to organizowanie w okresie letnim wycieczek dla młodzieży, pielgrzymek i procesji.

W 1961 r. stosunkowo najliczniej omawiane wykroczenia występowały w wojew. rzeszowskim, koszalińskim, warszawskim, krakowskim i lubelskim. W obu ostatnich zaznaczył się w porównaniu z rokiem $1960 \mathrm{w}$ sprawach zbiórek publicznych i zgromadzeń widoczny spadek liczby wniosków o ukaranie /średnio z 600 w ciągu III kwartałów 1960 r. do 200 w 1961 r./. 
Przeprowadzone przez inspektorów MSW rozmowy z członkami powiatowych instancji partyjnych, oficerami ds. bezpieczeństwa oraz członkami prezydiów rad narodowych, pozwalają na stwierdzenie iż organy powołane do ujawniania tych wykroczeń nie mają dokładnego rozeznania, czy ilość skierowanych wniosków do kolegiów k-a odpowiada ilości faktycznie popełnionych wykroczeń.

W ujawnionych w $1961 \mathrm{r}$. nielegalnych zbiórkach publicznych zdołano zabezpieczyć z reguły tylko małe kwoty /od 100 do 1000 zł./. Organy powołane do ścigania tych wykroczeń stwierdzają autorytatywnie, iż tylko tyle ofiar zdołano zebrać do momentu ujawnienia zbiórki.

Wprawdzie twierdzenie to budzi pewne wątpliwości ale nie zdołano znaleźć odpowiednich materiałów obalających lub potwierdzających powyższa tezę.

Mimo tak zasadniczego zmniejszenia wpływu wniosków o ukaranie do kolegiów, jakość tych wniosków, w zestawieniu z wnioskami w sprawach o inne wykroczenia /np. dot. wykroczeń z dziedziny komunikacji, handlu, itp./ pozostawia wiele do życzenia.

Wnioski te są z reguły niedostatecznie przygotowane przede wszystkim ze względu na niewłaściwe sformułowanie zarzutów i niewskazywanie odpowiednich dowodów.

Np. Powiatowa Komenda M.O. w Starogardzie /woj. gdańskie/ przesłała do kolegium k-a wniosek o ukaranie za używanie flagi o barwach biało-żółtych przez motocyklistę w czasie odprowadzania obrazu religijnego.

Wskazany we wniosku świadek oskarżenia nie potwierdził zarzutów /obwiniony do winy nie przyznał się/. Po dwukrotnym odraczaniu sprawy z uwagi na niestawienie się na rozprawę funkcjonariusza M.O. sporządzającego wniosek, funkcjonariusz ten zeznał, że "nie zna obwinionego, nie widział go w tym czasie i nic więcej w tej sprawie powiedzieć nie może".

Podobnie w sprawie 87/61 o ukaranie za zorganizowanie nielegalnej zbiórki, podany ze świadka funkcjonariusz M.O. zeznał, że „w tej sprawie nic nie wie, nic powiedzieć nie może, ponieważ w tym czasie na trasie służby nie pełnił”.

Pow. Komenda M.O. w Kutnie wystąpiła o ukaranie /sprawy nr 4148/61 i 4149/61/ za zorganizowanie zgromadzenia - pielgrzymki bez zezwolenia nie podając żadnych dowodów/świadków/ poza zdjęciem przedstawiającym kilkanaście kobiet. 
Stwierdzono również, że w pow. Hrubieszów zorganizowano pod oknami posterunku M.O. w Drohobyczu nielegalną zbiórkę publiczną. Sprawców wykroczenia nie wykryto.

Ta sytuacja i stanowisko jakie zajmują funkcjonariusze M.O. na rozprawach zmusza do zastanowienia się jakie mogą być

przyczyny niewłaściwego sporządzania wniosków, braku ich dokumentacji, niezabezpieczania przedmiotów, bądź ofiar pochodzących z nielegalnych zbiórek itp.

Podane wyżej fakty i rozmowy przeprowadzone w komitetach partyjnych z funkcjonariuszami wydziałów III komend wojewódzkich M.O. oraz oficerami $\mathrm{d} / \mathrm{s}$ bezpieczeństwa komend powiatowych M.O. pozwoliły na utwierdzenie się kontrolujących w przekonaniu, że silne oddziaływanie środowiska kościelnego przy słabym równocześnie politycznym przeciwdziałaniu podstawowych organizacji partyjnych, komend M.O., prezydiów rad narodowych na ten aparat, jest jedna z zasadniczych przyczyn stwierdzonego stanu rzeczy. Również i organa architektury i nadzoru budowlanego nie zawsze stosują środki przymusu administracyjnego w stosunku do osób, które nielegalnie wznoszą obiekty sakralne, dokonują przeróbek bądź zmieniają przeznaczenie lokalu oraz nie popierają wniosków o ukaranie na rozprawach przed kolegiami.

Przedstawiona sytuacja wydaje się tym bardziej dziwna, że we wszystkich kontrolowanych jednostkach powołano przy komitetach powiatowych PZPR odpowiednie zespoły, które analizują, ustalają zasady postępowania nawet $\mathrm{w}$ konkretnych indywidualnych sprawach będących przedmiotem rozpatrywania kolegium, kontrolują i wydają wytyczne do ścigania tych wykroczeń.

Wydaje się jednak, że cały ten wysiłek władz terenowych przy organizowaniu przeciwdziałań ma charakter raczej formalny. Za tym stwierdzeniem przemawiają wyniki kontroli i brak należytej organizacji władz o zasięgach i zamierzeniach niepraworządnej działalności kleru.

\section{Składy orzekające}

Do rozpatrywania spraw związanych z działalnością kleru i tzw. aktywu przykościelnego - zgodnie z zaleceniami Ministerstwa - utworzono w kolegiach k-a w miesiącu wrześniu br. specjalne składy orzekające, do których weszli wypróbowani członkowie kolegiów k-a, działacze powiatowi. 
Typowaniem kandydatów zajęły się urzędy i wydziały spraw wewnętrznych. Każda kandydatura była uzgadniana z właściwymi władzami partyjnymi.

Członkowie powołani do tych składów orzekających są obecnie szkoleni zarówno w zakresie zagadnień politycznych jak i zagadnień bezpośrednio związanych z wykroczeniami, które będą przez nich rozpatrywane.

$\mathrm{Na}$ kilkugodzinnych zajęciach przeważnie prowadzonych przez kierowników wydziałów spraw wewnętrznych, omawiane są obowiązujące przepisy oraz ostatnie wytyczne Ministerstwa. W niektórych województwach /np. w woj. poznańskim/ zajęcia przeprowadza się wspólnie z funkcjonariuszami M.O.

Stwierdzono jednak, że na szkoleniach tych główny nacisk położono na kwestię przepisów prawnych pomijając lub niedostatecznie doceniając potrzebę wykładów politycznych i aktualnego informowania o poczynaniach kleru.

\section{Polityka represyjna}

A. Represja k-a w tych sprawach jest w zasadzie prawidłowa. Kolegia we właściwym stopniu realizują zasadę indywidualizacji winy i kary.

Przykładem tego mogą być między innymi następujące orzeczenia: Kolegium powiatowe w Koninie za zorganizowanie zbiórki publicznej bez zezwolenia ukarało ks. Franciszka Bartczaka grzywną 1.500 zł. Za podobne wykroczenia 75-letniemu Józefowi Bocheńskiemu - utrzymującemu się z alimentów płaconych przez dzieci - wymierzono karę nagany.

Kolegium k-a przy Prezydium DRN w Warszawie ukarało za nielegalne budownictwo sakralne administratora parafii ks. Nowotko grzywną w wysokości 3000 zł, a kierownika nadzoru technicznego tej budowy grzywną w wysokości 3500 złotych.

$$
-6-
$$

Za podobne wykroczenia ukarano ks. Stwosza z Warszawy grzywną $4.000 \mathrm{zl}$.

Kolegium powiatowe we Włodawie ukarało ks. Turskiego grzywną 1.500 zł oraz orzekło przepadek 16.000 zł pochodzących ze zbiórki publicznej. 
Ukarano ponadto 5 osób, które przeprowadzały zbiórkę grzywnami od 800 do 1200 złotych.

Również grzywną 1.500 zł oraz przepadek 17.000 zł. orzekło kolegium powiatowe w Hrubieszowie w sprawie ks. Stanisława Mamcarza.

M.in. kolegium karno-administracyjne przy Prezydium PRN w Kutnie ukarało 3 staruszki w wieku 65-70 lat /wdowy i rencistki/ grzywnami 100-200 złotych, za zorganizowanie nielegalnych zbiórek /nr rej. 346/61, 348/61, 349/61/.

Należy podkreślić, że obowiązujące dotychczas przepisy dotyczące zbiórek publicznych i zgromadzeń, które są najczęściej naruszane, pochodzą z lat 1932 i 1933 i zawierają stosunkowo niskie sankcje karne za ich naruszenie - do 1500 złotych, a za nieuzgodnienie porządku procesji ulicznych, związanych z uroczystościami Bożego Ciała, zaledwie do 750 zł.

Przygotowane projekty nowych ustaw przewidują sankcje o wiele surowsze, bo do 4500 zł. Jednakże zwłoka w ich uchwaleniu/np. projekt ustawy o zbiórkach publicznych od czerwca br. znajduje się w Sejmie, a ustawa o zgromadzeniach przedstawiona Radzie Ministrów w czerwcu br. został przekazany do Sejmu dopiero w miesiącu październiku/ - w poważnym stopniu utrudnia zwalczanie tych wykroczeń.

B. Orzeczeń o uniewinnieniu wydano stosunkowo mało, a najistotniejszą przyczyną były wadliwie opracowane wnioski przez M.O. i niewystarczające materiały dowodowe.

Orzeczenia o ukaraniu niską grzywną były nieliczne i w zdecydowanej większości uzasadnione. Zdarzają się jednak przypadki wymierzania kar zdecydowanie zbyt łagodnych.

Kolegium powiatowe w Międzychodzie ukarało ks. J. Kasiewicza grzywną 200 zł - za zorganizowanie zgromadzenia publicznego/pielgrzymki/.

Kolegium przy prezydium PRN w Kaliszu ukarało ks. M. Dławichowskiego grzywną w wysokości 300 zł za nieuzgodnienie trasy procesji, organizowanej z okazji Bożego Ciała, a ks. Z. Wiewiórkowskiego za podobne wykroczenie grzywną w wysokości 250 zł.

Niepokojący jest fakt, że w takich przypadkach organy prokuratury i M.O. oraz wydziały d/s wyznań mimo posiadanych uprawnień, nie wnoszą odwołań i nie zaskarżają tych orzeczeń w trybie nadzoru. 
C. Mimo tej $\mathrm{w}$ zasadzie pozytywnej oceny polityki represyjnej stosowanej przez kolegia k-a, trzeba stwierdzić, że w sumie nie jest ona tak dotkliwa, przede wszystkim w stosunku do kleru, gdyż nie godzi jak to miało miejsce w 1959 r. i w 1960 r. - w najczulsze jego miejsce. Decydujące w polityce represyjnej w ubiegłych latach było bowiem przechwycenie przez organa donoszące w skali krajowej milionowych kwot, pochodzących z nielegalnych zbiórek, w stosunku do których kolegia orzekły przepadek.

D. Odnosi się również wrażenie, iż niektóre kolegia karnoadministracyjne, nie chcąc spotkać się z zarzutem tolerancyjności i liberalizmu ze strony miejscowych czynników w spawach wykroczeń kleru i tzw. aktywu przykościelnego, stosują często nieuzasadnioną zbyt ostrą represję, a nawet zdarza się, że wydają orzeczenia skazujące za czyny niezabronione obowiązującymi przepisami prawa, tłumacząc to sugestią z zewnątrz.

M. in. kolegium k-a przy Prezydium PRN w Bartoszycach woj. olsztyńskie ukarało ks. Szczepkowskiego grzywną w wysokości 1500 zł mimo, że za te wykroczenie przepisy ustawy o zgromadzeniach przewidują grzywnę do $750 \mathrm{zł}$.

Kolegium II instancji orzeczenie to zatwierdziło a przewodniczący kolegium przy Prezydium WRN w Olsztynie oświadczył, że otrzymał zalecenie w sprawie surowego ukarania księdza.

$$
-8-
$$

Kolegium Powiatowe w Jaśle w sprawie Nr 286/61 ukarało ks. Kawulę grzywną za zorganizowanie zbiórki publicznej oraz orzekło przepadek zebranego nielegalnie zboża nie ustosunkowując się do wyjaśnień ukaranego, że część zboża nie pochodziła ze zbiórki.

Kolegium Wojewódzkie w Rzeszowie orzeczenie to zatwierdziło, przy czym udzielono podobnych jak wyżej wyjaśnień.

W sprawie Nr 409/61 kolegium powiatowe w Kaliszu ukarało ob. Janiaka grzywną w wysokości 1500 zł za zorganizowanie nielegalnego zgromadzenia publicznego/zebranie 11 Świadków Jehowy w jego mieszkaniu/. Kolegium Wojewódzkie w Poznaniu orzeczenie I instancji zatwierdziło. Obwiniony na rozprawie w I i II instancji stwierdził, ze wszystkie zgromadzone $\mathrm{w}$ jego mieszkaniu osoby były mu znane osobiście. Stwierdzenie to w toku postępowania nie zostało obalone. Podobne uchybienia występują na terenie woj. wrocławskiego.

Nadmienia się, iż fakt osobistej znajomości zachodzący między zwołującym zebranie i jego uczestnikami wyklucza możliwość pociągania zwołującego zebranie do odpowiedzialności k-a. 
Kolegium k-a przy prezydium DRN Warszawa-Śródmieście ukarało ob. Biskupskiego grzywną w wysokości 350 zł za zainstalowanie w kościele Św. Anny w Warszawie urządzeń radiofonicznych bez pozwolenia.

Na rozprawie przed kolegium I instancji obwiniony wyjaśnił, że jest palaczem, na urządzeniach radiofonicznych nie zna się i tylko pomagał je przenosić. Kolegium II instancji po rozpoznaniu sprawy zatwierdziło orzeczenie.

E. Szybkość rozpatrywania spraw przez kolegia od czasu otrzymania wniosku nie budzi zastrzeżeń. Kolegia k-a zgodnie

z otrzymanymi wytycznymi, dość szybko rozpatrują te sprawy tj. przeciętnie w terminie do 20 dni od daty wpływu wniosku.

Stwierdzono natomiast, że organy M.O. niejednokrotnie nadsyłają wnioski o ukaranie po upływnie dwu lub więcej miesięcy od chwili popełnienia wykroczeń.

Np. w pow. Zamość w dniu 7 lutego 1961 r. nadesłano wniosek o ukaranie za wykroczenie popełnione w listopadzie ub. r. /sprawa Nr 4961/61/. W pow. Hrubieszów w sprawach Nr 398/61, 421/61, 422/61, 423/52 i 491/61 wnioski wpłynęły do kolegium k-a po upływnie około 2 miesięcy od chwili popełnienia wykroczenia.

Często jednak przyczyną tego są trudności w ustaleniu sprawców wykroczeń.

\section{Wykonanie kary}

Realizacja orzeczonych przez kolegia kar przebiega w zasadzie prawidłowo. W ciągu III kwartału $1961 \mathrm{r}$. w porównaniu z analogicznym okresem roku ub. znacznej poprawie uległo wykonanie kar.

Wokresiesprawozdawczym wykonanocałkowicie $138 \%$ prawomocnych kar grzywien, tj. około 73\% ogólnej ilości kar do wykonania. W ub.r. natomiast, wykonano w ciągu III kw. zaledwie 64\% prawomocnych kar.

Na dzień 30 września $1961 \mathrm{r}$. pozostało w trakcie wykonania 317 kar.

W sprawach zbiórek publicznych, gdzie obok kar zasadniczych orzeczono przepadek zebranych kwot, wykonano $86 \%$ kar przepadku na łączną sumę około $300.000 \mathrm{zł}$. 
Mają jednak miejsce przypadki pewnych uchybień, ale są one sporadyczne i w zasadzie tylko w minimalnym stopniu rzutują na odsetek wykonanych kar.

Np. w sprawie ks. Wiewiórkowskiego z pow. Kalisz w dniu 10.VI.1961 r. przesłano organom finansowym

tytułwykonawczy. Do dnia 13.X. Wydział Finansowy nie wyegzekwował grzywny.

W pow. Koło w sprawie Nr 46/61 w dniu 30.V.1961 r. wezwano zakonnicę T. Kałużną do wpłacenia grzywny. Ukarana do dnia 14.X.61 r. grzywny nie wpłaciła. Nie wezwano jej do odbycia zastępczej kary aresztu.

Ukarani w zasadzie uiszczają orzeczone grzywny we właściwych terminach. W kontrolowanych województwach i powiatach nie osadzono dotąd żadnego księdza w areszcie.

\section{Punkty katechetyczne}

Obecnie przedmiotem szczególnego zainteresowania władz terenowych jest zagadnienie punktów katechetycznych.

Realizacja zarządzenia Ministra Oświaty z dnia 18 sierpnia $1961 \mathrm{r}$. przebiega niezadowalająco.

Znikoma ilość zgłoszonych punktów katechetycznych, zawartych umów, ignorowanie przez kler postanowień zarządzenia - stwarza konieczność skoordynowania działania organów zainteresowanych tym zagadnieniem.

Niepokojącym jest fakt, że na terenie niektórych województw inspektoraty oświaty ograniczają się do kierowania do kolegiów znacznej ilości wniosków o ukaranie za prowadzenie nauki religii w niezarejestrowanych punktach katechetycznych.

Np. do dnia 23.X. br. do kolegiów na terenie woj. rzeszowskiego skierowano 34 wnioski . Do kolegium przy Prezydium PRN w Kielcach inspektorat oświaty do dnia 20.X. br. skierował 32 wnioski. Wnioski te są opracowane bardzo lakonicznie i schematycznie. Opis czynu zarzucanego obwinionemu najczęściej brzmi: „w niezarejestrowanym punkcie... prowadził naukę religii”.

Wydaje się, że w żadnym przypadku nie można się zgodzić na to, aby tak sformułowany opis czynu stanowił podstawę do wszczęcia postępowania. Kolegia k-a mogłyby spotkać się z zarzutem przy takim określeniu zarzucanego czynu, że wymierzają kary „za nauczanie religii”. 
We wszystkich tych wnioskach jako podstawę prawną podaje się art. 25 ustawy o zgromadzeniach publicznych /a faktycznie może on mieć zastosowanie tylko do nielicznych i indywidualnych przypadkach/. Jako podstawę prawną pociągnięcia do odpowiedzialności k-a /w zależności od konkretnego przypadku/ można stosować między innymi art. 27 prawa o wykroczeniach, przepisy sanitarne, przeciwpożarowe lub prawa budowlanego.

Przedstawiona sytuacja wskazuje, że inspektoraty oświaty idą po najmniejszej linii oporu i nie wykazują dostatecznego zrozumienia dla politycznego znaczenia stosowania $\mathrm{w}$ tych sprawach właściwych metod działania.

Wydaje się, że problem ten nie może być rozwiązany tylko przez stosowanie nawet najbardziej ostrych sankcji k-a /na co słusznie wskazują niektóre województwa/. Bardziej celowym i skutecznym środkiem byłoby stosowanie przepisów o postępowaniu przymusowym $\mathrm{w}$ administracji, z których dotąd nie korzystają inspektoraty oświaty i w niektórych sprawach represji karno-administracyjnej.

Wątpliwości budzi fakt podejmowania prób wyciągania konsekwencji w pierwszej kolejności w stosunku do osób prowadzących punkty katechetyczne w obiektach sakralnych, których jest stosunkowo dużo.

W woj. gdańskim na zorganizowanych do dnia 10 października br. 295

punktów katechetycznych - 237 tj. 80\% powstało w kościołach bądź w innych obiektach sakralnych.

W związku z przedstawioną sytuacją, zdaniem Departamentu, należałoby podjąć następujące środki zmierzające do dalszej poprawy istniejącego stanu:

\section{W zakresie kolegiów karno-administracyjnych}

1. Położyć większy nacisk na szkolenie polityczne specjalistycznych zespołów orzekających. Wytypowane w m-cu wrześniu br. zespoły orzekające mające rozpatrywać wyłącznie

sprawy naruszeń przepisów przez kler i tzw. aktyw przykościelny wymagają stałej opieki i pomocy. Do szkolenia politycznego i z dziedziny prawa należałoby zaangażować zawodowych wykładowców $\mathrm{z}$ woj. ośrodka szkolenia partyjnego przygotowanych w zakresie spraw światopoglądowych i zoriento- 
wanych $\mathrm{w}$ aktualnej sytuacji politycznej na tym odcinku $\mathrm{w}$ kraju, $\mathrm{z}$ wojewódzkiego aparatu spraw wewnętrznych i prokuratur $\mathrm{w}$ zakresie potrzebnych wiadomości prawa formalnego i materialnego. Wykłady w tych trudnych i skomplikowanych sprawach powinny być przygotowane w sposób przystępny i kończyć się seminariami w których członkowie kolegiów winni wykazać swój stopień opanowania potrzebnych wiadomości, które dla rozpatrywania spraw związanych z działalnością kleru musi być wysokie, zważywszy, że ta grupa obwinionych posiada przeważnie wyższe wykształcenie i dobrą znajomość prawa.

2. Opracować dla potrzeb kolegiów i organów M.O. aktualny zbiór przepisów z omawianych dziedzin zaopatrzony w komentarz, który będzie pomocą przy szkoleniu, ujawnianiu wykroczeń i orzekaniu.

3. Spowodować aby w większym aniżeli dotąd stopniu wydziały d/s wyznań interesowały się sprawami, które mają być przedmiotem rozpatrywania przez kolegium, udzielały potrzebnych porad, informacji a w razie potrzeby przy skomplikowanych sprawach stawały na rozprawie w charakterze świadków bądź rzeczoznawców, a w przypadku niesłusznej kary orzeczonej przez kolegium powodowałyby zaskarżanie tych orzeczeń.

4. Spowodować aby każde niesłuszne orzeczenie nie tylko było uchylone ale i żeby przewodniczący kolegium błędy poczynione przy orzekaniu spraw szczegółowo omówił z tym składem orzekającym, który wydał orzeczenie.

5. Spowodować, aby wydziały spraw wewnętrznych i wydziały finansowe bardziej konsekwentnie przestrzegały terminowości przy spełnianiu czynności, zmierzających do wykonania prawomocnych orzeczeń.

6. W związku z tym, że inspektorzy MSW zostali poinformowani przez terenowych oficerów d/s bezpieczeństwa o otrzymaniu przez księży wyraźnych dyrektyw, aby nie płacili orzeczonych kar grzywny lecz decydowali się na odbycie kary aresztu, zachodzi potrzeba sprecyzowania stanowiska, czy kolegia k-a mają orzekać karę aresztu zastępczego i w przypadku nieuiszczenia zamienionej na ten areszt kary grzywny w terminie - konsekwentnie ją wykonywać. 


\section{W zakresie organów ujawniających wykroczenia}

1. Stwierdzona w niniejszej informacji sytuacja wymaga aby zwłaszcza kierownictwo organów M.O. podjęło odpowiednie bardziej zdecydowane środki, mające na celu wyeliminowanie wpływów środowisk klerykalnych na niektórych ich pracowników.

2. Wskazanym byłoby aby instancje partyjne w oparciu o analizę sytuacji i konkretnie stwierdzone przykłady niedociągnięć na danym terenie omówiły w komendach M.O. polityczną wagę tych wykroczeń, sposoby zapobiegania im oraz środki zwalczania. Należałoby wpłynąć na funkcjonariuszów M.O., zwłaszcza członków Partii aby sprawom tym poświecili więcej uwagi.

3. Należałoby udzielić bardziej jasnych i sprecyzowanych dyrektyw służbie bezpieczeństwa jak ma postępować z ujawnionymi operacyjnie faktami łamania przepisów, aby z jednej strony nie dekonspirować się a z drugiej strony dostarczyć organom orzekającym potrzebnych dowodów i świadków.

4. W przypadkach ujawniania nielegalnych zbiórek publicznych w szerokim zakresie należy zabezpieczać zebrane sumy bądź naturalia.

5. Okres od ujawnienia wykroczenia do wpływu wniosku o ukaranie winien ulec znacznemu skróceniu - do 7 dni.

6. Organa Milicji Obywatelskiej i Prokuratury powinny w szerszym zakresie składać odwołania od niesłusznych orzeczeń bądź zaskarżać je w trybie nadzoru.

7. Na terenie całego kraju - wzorem woj. poznańskiego funkcjonariusze M.O. winni być poddani szkoleniu wspólnie ze składami orzekającymi kolegiów k-a w zakresie przepisów dotyczących określonych dziedzin wykroczeń.

8. W czasie organizowanych obecnie szkoleń należy w zajęciach ze słuchaczami omówić szeroki wachlarz przepisów dotyczących wykroczeń związanych z działalnością kleru, co pozwoli na odpowiednią kwalifikację poszczególnych czynów. 
9. Zlecić organom architektury i nadzoru budowlanego korzystanie ze środków przymusu administracyjnego w stosunku do osób naruszających przepisy prawa budowlanego i konsekwentne przestrzeganie realizacji tego zalecenia. Należałoby również spowodować, aby przedstawiciele tych organów występowali na rozprawach przed kolegiami w charakterze świadków bądź rzeczoznawców.

10. Inspektoraty oświaty winny - w stosunku do osób naruszających przepisy zarządzenia Ministra Oświaty z dnia 19 sierpnia br. - w pierwszym rzędzie wykorzystywać środki przewidziane w przepisach o postępowaniu przymusowym $\mathrm{w}$ administracji.

Warszawa, dnia 9 paźdz. 1961 r. DYREKTOR DEPARTAMENTU

/H. Chmielewski/

Oryginał, maszynopis.

Archiwum Akt Nowych, zespół akt: Urząd do Spraw Wyznań sygn. akt 61/978, s. 1-15. 